\title{
THE ANALYSIS OF STUDENTS' READING COMPREHENSION ABILITY AT INDONESIAN MARITIME ACADEMY, MEDAN
}

\author{
I Wy. Digeyasa ${ }^{1}$ and Lamhot Naibaho ${ }^{2}$ \\ ${ }^{1}$ English Education Department, Medan State University, Indonesia \\ ${ }^{2}$ English Education Department, Universitas Kristen, Indonesia
}
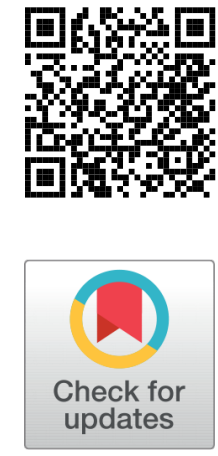

Received 17 June 2021

Accepted 2 July 2021

Published 31 July 2021

Corresponding Author

I Wy. Digeyasa, wayandirgayasa@ yahoo.com

DOI $10.29121 /$

granthaalayah.v9.i7.2021.4045

Funding: This research received no specific grant from any funding agency in the public, commercial, or not-for-profit sectors.

Copyright: (C) 2021 The Author(s). This is an open access article distributed under the terms of the Creative Commons Attribution License, which permits unrestricted use, distribution, and reproduction in any medium, provided the original author and source are credited.

\section{ABSTRACT}

This study is about the analysis of students' reading comprehension ability, it is done to find out how students' reading comprehension ability. This study was done at Indonesian Maritime Academy, Medan. The method of the study was quantitative with survey design. The instrument of the study used was a set of reading comprehension test which were constructed based on the taxonomic level. The respondent of this study were 83 respondents who were randomly selected, consisting of two students who studied English for almost two years at Indonesian Maritime Academy, Medan. The result is that the level of students' reading comprehension among students is at the moderate level and there is a significant relationship between reading comprehension and English language achievement. In conclusion, one way to improve student achievement in English language subjects is by increasing the level of students 'reading comprehension.

Keywords: Ability, Analysis, Reading Comprehension

\section{INTRODUCTION}

English reading skills is one of the language skills that are the main objective in the English curriculum. However, the mastery of English reading skills is still being questioned because the Lower Secondary Assessment Examination Report states that among the weaknesses of students in answering English examination papers is that they do not understand the meaning of words and sentence structure, even though the word level and sentence structure correspond to their level Joseph and Schisler (2009); Naibaho and Sangga (2019); Palacios and Kibler (2016). However, students have completed their studies at the secondary school level but have a low level of mastery in language skills Dirgayasa (2014); Naibaho (2019). In the reading test, some of the students cannot read correctly in terms of grammar, pronunciation of letters and are unable to form and write correct sentences according to the actual 
method of English Gough et al. (2017); Hunley et al. (2013). Reading comprehension can interpret and evaluate something entirely about what is being read Attaprechakul (2013); Dirgeyasa (2009). When a person does not understand what should be known, the person is not considered doing the reading process but only saying the words Coiro (2011). Reading skills are also a cognitive process, that is, understanding reading material into understandable meanings. The cognitive process involves six cognitive domains: knowledge, understanding, application, analysis, synthesis, and evaluation Hulya and Rifat (2011); Mathumbu et al. (2014). These six domains are thought processes performed by an individual directly in reading comprehension. The process of reading comprehension can be measured in its level. Several tests can measure students' reading comprehension Dirgayasa (2018); Naibaho (2021). Among them is the Taxonomy Reading Comprehension Test (TRCT).

This test is based on Bloom's Taxonomy, namely knowledge, understanding, application, analysis, synthesis and evaluation Chandio et al. (2016); Köksal and Ulum (2018). Based on this Taxonomy, Taxonomy reading comprehension questions are divided into six categories Naibaho (2020); Swart (2009), namely starting from the easiest to the most difficult; (1) Recognize and remember details; (2) Translation questions; (3) Application questions; (4) Analytical questions; (5) Synthesis questions; and (6) Evaluation questions. This study was conducted to see English reading comprehension among students by using this test, namely the Taxonomy Reading Comprehension Test (TRCT). The purpose of this study was to identify the level of reading comprehension of English according to taxonomy. More specifically, the objectives of this study were to: (1) Identify the level of reading comprehension skills of English texts among students through the Taxonomy Reading Comprehension Test; (2) Identify the relationship between the level of reading comprehension and the achievement of English subjects. Based on this specific objective, the research questions were constructed, namely: (1) What is the level of reading comprehension skills of English text among students through the Taxonomy Reading Comprehension Test; and (2) Is there a relationship between the level of reading comprehension and the achievement of English subjects.

\section{RESEARCH METHOD}

The study design that is appropriate to the objectives of this study is a survey study using a reading comprehension test as a research tool. The test used in this study is the TRCT. The TRCT set used two essay passages containing six structured comprehension questions for each essay passage. These comprehension questions are constructed based on the taxonomic level by referring to the hierarchy of reading comprehension skills. According to this hierarchy, there are six classifications of categories arranged according to level, from the easiest to the more complex, the categories are arranged as follows: (1) Recognizing and remembering details, (2) Translation questions, (3) Application questions (4) Questions analysis, (5) Synthe- 
sis questions and (6) Evaluation questions. This study involved 83 respondents who were randomly selected, consisting of two students who studied English for almost two years at Indonesian Maritime Academy, Medan. The students' final scores were used to identify student achievement. To interpret the test, this study uses the following grade assessment, i.e. 0-22 per cent is Very Poor, 23-39 per cent is Poor, 40-59 per cent is Moderate, 60-79 per cent is Good, 80-100 per cent is Very Good. This study uses the interpretation of Davies and Vincent's Readability Level to identify the action that needs to be taken on the level of the test scores, which is as follows: 75 per cent and above is the Independent Level, 50 per cent and below is the Guidance Level, 25 per cent to the bottom is the Disappointed Level, while 51-74 per cent are between the High Coaching Level or the Low Individual Level. The Solitary Level is the stage where the student has reached an excellent Reading and Comprehension Level and has demonstrated the ability to understand reading material independently without the need for assistance. The Guidance Stage is that students face some problems in reading material and comprehension and still need guidance. The Disappointed stage is that the student faces many problems in his reading and comprehension and feels frustrated.

\section{RESEARCH RESULT AND DISCUSSION}

Based on the study results, the level of reading comprehension of English texts among students for the taxonomic reading comprehension test is at a moderate level. The descriptive analysis is shown in Table 1, i.e. the average percentage is 48.5 per cent. This average percentage is closer to the Weak Level than the Good Level.

Table 1 TRCT Level

\begin{tabular}{|ccccc|}
\hline & N & Average (\%) & Achievement Level & Readability Interpretation Level Result \\
TRCT & 83 & 49.6 & moderate & guidance level \\
\hline
\end{tabular}

Table 2 shows the average percentage breakdown for each Taxonomy level in the test. Able to show the highest level of average percentage is the level of Recognizing and Remembering Details, which is 43.8 per cent. The order from highest to lowest is as follows: This level is followed by the Translation level, which is 41.8 per cent, then the Analysis level, which is 38.7 per cent, then the Synthesis level, which is 36.5 per cent, then the Application level, which is 35.8 per cent, and then the lowest level is the level evaluation, which averaged 35.5 per cent.

Table 2 also shows the distribution of Readability Levels for each taxonomic level. Based on the study's findings, two levels are at the level of Guidance, while the other four levels are at the level of Disappointment. Students still cannot read alone for the first and second levels, namely the Recognizing and Remembering Details Level and the Translation Level. They need guidance from anEnglish teacher. Students desperately need guidance from an English language teacher for Levels three to six, 


\begin{tabular}{cccc}
\hline Table 2 TRCL Category & Average \\
Taxonomy Level & $\begin{array}{c}\text { Achievement } \\
\text { Level }\end{array}$ & $\begin{array}{c}\text { Readability Interpretation Level } \\
\text { Result }\end{array}$ \\
\hline $\begin{array}{c}\text { criticize and remember } \\
\text { details }\end{array}$ & 43.8 & moderate & guidance level \\
translation & 41.8 & moderate & guidance level \\
application & 35.8 & poor & guidance level \\
analysis & 38.7 & poor & guidance level \\
synthesis & 36.5 & poor & guidance level \\
evaluation & 35.5 & poor & guidance level \\
\hline
\end{tabular}

which is the Disappointed Level.

hows the achievement of theEnglish subjects of the study respondents for the final year examination of form one. Table 3 shows that 30 per cent of respondents got grade A, 23.3 per cent of respondents got grade B, 25 per cent of respondents got grade $\mathrm{C}$, and 21.7 per cent of respondents got grade $\mathrm{D}$.

\begin{tabular}{ccc}
\hline Table 3 Students' Final Score & & \\
\hline Grade & N & \% \\
A & 26 & 31 \\
B & 20 & 24 \\
C & 21 & 25 \\
D & 16 & 20 \\
\hline
\end{tabular}

The correlation coefficient test is shown in Table 4 The study's findings found that the value of $r$ is $r=0.613$ at the significance level of 0.05 . It indicates that reading comprehension has a positive relationship with the achievement of English listening subjects. The strength of the relationship between the two variables is at a high level of relationship, i.e. between $r=0.61$ to $r=0.80$. It indicates that students who have high reading comprehension also get high results in the achievement of English subjects. Therefore, it can be concluded that the higher the taxonomic reading comprehension, the higher the achievement of English subjects. Similarly, conversely, the lower the motivation for learning listening skills, the lower the achievement of English listening skills.

\section{Table 4 Results of the Reading Comprehension Correlation Coefficient Analysis with Student Achievement}

The relationship between TRCT variables and Reading Achievement $\quad$ r 0.624* Sig. 0.05

${ }^{*}$ significant at the level of $=0.05$

In general, the study's findings show that the level of reading comprehension of the Taxonomy of the respondents is at a moderate level. It is based on the results of 
the Taxonomy Reading Comprehension Test. The results of this study are not much different from the results of those who found that the level of reading skills among students Kadir et al. (2014). However, the findings of this study are slightly different from the findings of the study that found the mastery of reading comprehension among secondary schools at the primary level Tahar et al. (2010). Similarly, the findings in the same study secondary school found at a weak level.

Similarly, a study found that students in secondary schools had low achievement in English subjects, where students lacked the vocabulary and were unable to make sentence structures well Sunarto and Naibaho (2021). This difference can be referred to the difference of the test used to identify the level of reading comprehension; i.e. previous studies were more focused on identifying English vocabulary mastery in reading comprehension. This study uses the Taxonomy Reading Comprehension test to identify reading comprehension, which is the focus to identify the level of reading comprehension according to Bloom's Taxonomy.

Although the findings of this study found that the level of reading comprehension at the Medium level, but in a breakdown of each of the six taxonomic levels, the findings show that respondents get only one level at the Medium level, namely the level of recognizing and remembering details. This level is the first level in Bloom's Taxonomy, i.e. the student only needs to recall the information or facts found in the passage he or she reads. In this first-level question, most respondents should be able to answer correctly, and the average percentage should be at a good or excellent level because this level question is a literal question of the text, not an inferential from Dirgeyasa (2017); Veeravagu et al. (2010). The findings show that the respondents' answers are at a Moderate level. At the same time, this indicates that respondents have trouble answering this level questions, not to mention more complex questions of this level Holbrook et al. (2006). Thus, the study's findings found that the average percentage for the remaining taxonomic levels were at the Weak level, namely the level of Translation, Application, Analysis, Synthesis, and Evaluation. The findings also show that the lowest level of average percentage is the Assessment level. The valuation level is the highest in Bloom's Taxonomy. It indicates that the level of reading comprehension of the respondents is still at the level of recognizing and remembering details, and they cannot do them when they are reading material to a higher level.

Meanwhile, the findings of this study from the aspect of Readability Level show that there is no single level at the Individual Level, that is, the level of students can read on their own and does not need guidance from teachers to understand the reading material. Instead, two levels at the Guidance Stage and four levels at the Disappointed Stage. The two levels at the Guidance Level are the Recognizing and Remembering Details level and the Translation level. The other four levels at the Disappointed Stage are the Application, Analysis, Synthesis and Evaluation levels Ulum (2016). The Guidance Stage means that the student faces some problems in reading and comprehension material and still needs guidance, while the Disappointed 
Stage means that the student faces many problems in his reading and comprehension, and he feels frustrated to comprehend the reading material. At the same time, these findings indicate that students cannot read alone but need guidance from the teacher and even need more guidance for higher levels Armbruster (2010).

The findings of this study also mean that students cannot read English reading material without teacher guidance. Pupils must rely on the teacher to understand the English reading material. Therefore, students cannot understand English reading materials outside of school hours because there is no guidance from the teacher. As a consequence, students will not do English revision outside of school hours. Ultimately, this situation will have a negative impact on student achievement in English subjects.

This matter needs to be considered by the relevant parties, especially the teachers and curriculum drafters, as students cannot revise their outside of school hours without the teacher's guidance. The findings of the correlation test showed that there was a significant relationship between reading comprehension and the achievement of English language subjects. It shows that the achievement of English language subjects depends on the level of reading comprehension. That is, the higher the level of reading comprehension, the higher the achievement of English.

\section{CONCLUSION}

This study has been able to identify that the level of students' reading comprehension among students is at the moderate level. Nevertheless, the more detailed reading comprehension level is the reading level according to the taxonomy level, where it is found that the first level of taxonomy is at the Medium level, while the remaining level is at the Weak level. In the meantime, this study has also been able to identify the level of readability according to Bloom's Taxonomy among students, namely the first and second levels at the Guidance Level and the remaining levels at the Disappointed Level. The results of this Readability Level can guide teachers to take action to improve the level of reading comprehension in English among students. This study has also shown that there is a significant relationship between reading comprehension and English language achievement. In conclusion, one way to improve student achievement in English language subjects is by increasing the level of students 'reading comprehension.

\section{REFERENCES}

Armbruster, B. B. (2010). Put Reading First: The Research Building Blocks For Teaching Children To Read: Kindergarten Through Grade 3.

Attaprechakul, D. (2013). Inference Strategies to Improve Reading Comprehension of Challenging Texts. English Language Teaching, 6(3), 82-91. Retrieved from https://dx.doi .org/10.5539/elt.v6n3p82 10.5539/elt.v6n3p82

Chandio, M. T., Pandhiani, S. M., \& Iqbal, S. (2016). Bloom's Taxonomy: Improving Assess- 
ment and Teaching-Learning Process. Journal of Education and Educational Development, 3(2), 203-203. Retrieved from https://dx.doi.org/10.22555/joeed.v3i2.1034 10.22555/joeed.v3i2.1034

Coiro, J. (2011). Predicting Reading Comprehension On The Internet: Contributions of Offline Reading Skills, Online Reading Skills, And Prior Knowledge. Journal Of Literacy Research, 43(4), 352-392.

Dirgayasa, I. W. (2014). Survey of English Teaching and Learning Process in Maritme Education and Training in Indonesia: A Case Study in Private MET in Indonesia. English Language Teaching, 7(7), 111-119. Retrieved from https://dx.doi.org/10.5539/elt .v7n7p111 10.5539/elt.v7n7p111

Dirgayasa, I. W. (2018). Exploring The Maritime Words: An Introduction., 2.

Dirgeyasa, I. W. (2009). The Nature Of Maritime English And Its Current Issue.

Dirgeyasa, I. W. (2017). Model answers for Yes/No questions from EFL students in public senior high schools. Studies in English Language and Education, 4(2), 235235. Retrieved from https://dx.doi.org/10.24815/siele.v4i2.7717 10.24815/siele .v4i2.7717

Gough, P. B., Juel, C., \& Griffith, P. L. (2017). Reading, Spelling, And The Orthographic Cipher. Reading Acquisition, 35-48.

Holbrook, A., Cho, Y. I., \& Johnson, T. (2006). The Impact of Question and Respondent Characteristics on Comprehension and Mapping Difficulties. Public Opinion Quarterly, 70(4), 565-595. Retrieved from https://dx.doi.org/10.1093/poq/nfl027 10.1093/ $\mathrm{poq} / \mathrm{nfl} 027$

Hulya, A. E., \& Rifat, E. (2011). Evaluating the effect of computer simulations on secondary biology instruction: An application of Blooms taxonomy. Scientific Research and Essays, 6(10), 2137-2146. Retrieved from https://dx.doi.org/10.5897/sre10.1025 10.5897/ sre10.1025

Hunley, S. A., Davies, S. C., \& Miller, C. R. (2013). The Relationship between Curriculum-based Measures in Oral Reading Fluency and High-Stakes Tests for Seventh Grade Students. RMLE Online, 36(5), 1-8. Retrieved from https://dx.doi.org/10.1080/19404476.2013 $.1146209810 .1080 / 19404476.2013 .11462098$

Joseph, L. M., \& Schisler, R. (2009). Should Adolescents Go Back To The Basics? A Review Of Teaching Word Reading Skills To Middle And High School Students. Remedial And Special Education, 30(3), 131-147.

Kadir, A., Subki, N., Jamal, R., Ismail, F., \& J. (2014). The Importance Of Teaching Critical Reading Skills In A Malaysian Reading Classroom. International Academic Conference, 208218.

Köksal, D., \& Ulum, Ö. G. (2018). Language Assessment Through Bloom's Taxonomy. Journal of Language And Linguistic Studies, 14(2), 76-88.

Mathumbu, D., , Rauscher, W., \& Braun, M. (2014). Knowledge and cognitive process dimensions of Technology teachers' lesson objectives. South African Journal of Education, 34(3), 1-8. Retrieved from https://dx.doi.org/10.15700/201409161053 10.15700/ 201409161053

Naibaho, L. (2019). The Effectiveness Of Independent Learning Method On Students' Speaking Achievement At Christian University Of Indonesia Jakarta. Asian Efl Journal, 23(6), 142-154.

Naibaho, L. (2020). THE EFFECTIVENESS OF NUMBER HEAD TOGETHER STRATEGY ON IMPROVING STUDENTS' ENGLISH ACHIEVEMENT AT XYZ SCHOOL. International Journal of Research -GRANTHAALAYAH, 7(10), 362-370. Retrieved from https://dx.doi.org/ 
10.29121/granthaalayah.v7.i10.2019.406 10.29121/granthaalayah.v7.i10.2019.406

Naibaho, L. (2021). Psycholinguistics In Language Learning.

Naibaho, L., \& Sangga, R. E. (2019). Improving Eight Graders' Reading Comprehension Using Student Team Achievement Division (Stad) At Smp Strada Santo Fransiskus.

Palacios, N., \& Kibler, A. (2016). Oral English language proficiency and reading mastery: The role of home language and school supports. The Journal of Educational Research, 109(2), 122-136. Retrieved from https://dx.doi.org/10.1080/00220671.2014.927341 10 $.1080 / 00220671.2014 .927341$

Sunarto, E., \& Naibaho, L. (2021). Effective School Management In Industrial.

Swart, A. J. (2009). Evaluation Of Final Examination Papers In Engineering: A Case Study Using Bloom's Taxonomy. Ieee Transactions On Education, 53(2), 257-264.

Tahar, M. M., Toran, H., Mohd, M. H., \& Bari, S. (2010). Reading skills among year one students in Malaysia. Procedia - Social and Behavioral Sciences, 9, 378-383. Retrieved from https://dx.doi.org/10.1016/j.sbspro.2010.12.168 10.1016/j.sbspro.2010.12.168

Ulum, Ö. G. (2016). A Descriptive Content Analysis Of The Extent Of Bloom's Taxonomy In The Reading Comprehension Questions Of The Course Book Q: Skills For Success 4 Reading And Writing. Qualitative Report, 21(9).

Veeravagu, J. V. J., Muthusamy, C., Marimuthu, R., \& Michael, A. S. (2010). Using Bloom's Taxonomy To Gauge Students' Reading Comprehension Performance. Canadian Social Science, 6(3), 205-212. 